ELORE (ISSN 1456-3010), vol. $16-1 / 2009$.

Julkaisija: Suomen Kansantietouden Tutkijain Seura ry.

[http://www.elore.fi/arkisto/1_09/ajank_kortelainen_01_09.pdf]

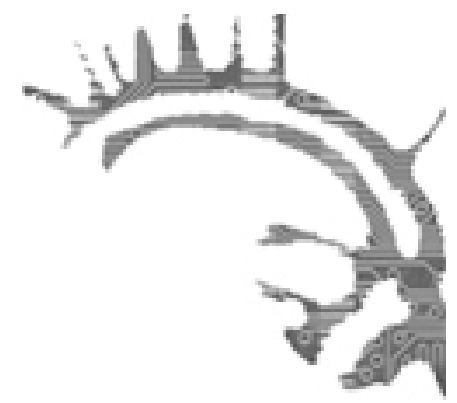

Ajankohtaista:

\title{
MuISTITIETOTUTKIMUS TYÖLÄISYYDESTÄ SAHAYHTEISÖSSÄ
}

Lectio praecursoria Joensuun yliopistossa 29.11.2008

$\underline{\text { Kaisu Kortelainen }}$

\section{Merkitysten MUistitieto}

Muistitieto kuuluu meidän kaikkien elämään. Se on tietoa, joka jäsentää menneisyyttämme, kertoo meille, miten olemme päätyneet tähän hetkeen ja pohjustaa myös ajatuksiamme tulevaisuudesta. Tämä tieto välittyy meille monista eri lähteistä. Oma elämänhistoriamme ja omat kokemuksemme tapahtumista ovat oleellinen osa muistitietoa. Suullisesti välittyvä tieto, perheenjäsenten, sukulaisten ja tuttavien kertomukset ovat siinä myös keskeisessä asemassa. Enenevässä määrin muistitietoon sisältyy myös historian kirjojen ja median välittämää tietoa: sanomalehdet, televisio, radio ja internet ovat monenlaisen tiedon lähteitä. Muistitieto karttuu myös esimerkiksi esineistä, valokuvista ja kartoista. Siihen liittyy usein myös tunne-elämyksiä, ruumiinmuistia ja erilaisia aistikokemuksia kuten tuntemuksia, ääniä, tuoksuja ja hajuja sekä makuelämyksiä. Muistitieto sisältää kollektiivista, yhteistä jaettua tietoa sekä omia henkilökohtaisia kokemuksia, mielipiteitä ja näkemyksiä. Me kaikki olemme taitavia kokoamaan tätä monenlaista tietoa sekä järjestelemään sitä elämäämme ja näkemyksiimme sopiviksi loogisiksi kertomuksiksi siitä, mitä aikaisemmin on tapahtunut, mitä tapahtuu nyt, ja miksi tulevaisuus näyttää siltä kuin se näyttää. On selvää, että muistitieto on rajatonta. Sitä on loputon määrä, se uusiutuu ja muokkautuu koko ajan.

Kun muistitieto esiintyy kertomuksina, tulee siitä perinteentutkijalle haaste, johon ei voi olla tarttumatta. Perinteentutkimus tieteenalana on kiinnostunut erilaisten tutkimuksen kohteena olevien tekstien merkityksistä. Ei ole niinkään tärkeää, onko joku tapahtuma mennyt juuri niin kuin ihmiset kertovat. Tärkeämpää on se, mitä siitä kerrotaan. Perinteentutkijan näkökulmasta kerrottu muistitieto välittää aina jotakin oleellista. Väitöskirjatutkimuksessani olen tutkinut muistitietoa ajatellen, että sen 


\section{MUISTITIETOTUTKIMUS TYÖLÄISYYDESTÄ SAHAYHTEISÖSSÄ}

muuntuvuus, monipuolisuus, moniäänisyys ja rajattomuus ovat oleellinen osa tätä tiedonlajia.

Miten sitten tutkia tällaista tietoa, joka on rajatonta, muuttuvaa, ja jota on sanottu usein myös epäluotettavaksi tiedoksi? Mitä on muistitietotutkimus? Dosentti Ulla-Maija Peltonen on kirjoittanut artikkelissaan, joka julkaistiin vuonna 2006 kokoelmassa Muistitietotutkimus. Metodologisia kysymy/esiä, että muistitieto, kuten myös folklore, tuottaa "toista tietoa" menneisyydestä. Tutkijalle se kertoo erityisesti vallitsevista arvoista ja normeista. Lisäksi se antaa tietoa yhteisön arkielämästä sekä kertojien henkilökohtaisista kokemuksista ja näkemyksistä. Muistitietoa käytetään usein rinnakkain perinteisten historian tutkimuksen asiakirja-aineistojen kanssa, kuten Inkeri Ahvenisto on tehnyt aikaisemmin tänä syksynä ilmestyneessä väitöskirjassaan, jossa hän kuvailee Verlan ruukkitehtaan menneisyyttä. Ahvenisto kirjoittaa, että nämä erityyppiset aineistot kertovat eri asioista, ja niihin on myös sovellettava erilaisia tutkimusmenetelmiä. Itse olen keskittynyt nimenomaan muistitietoon, koska perinteisten historian arkistolähteiden käyttäminen rinnalla ehkä kahlitsisi liikaa näkemystäni tutkimuskohteesta eli Penttilän sahayhteisöstä. Tehdessäni tutkimusta etenin muistitiedon johdattamana, ja viittaukset muihin lähteisiin ovat sitä tarkentamassa ja tukemassa. Tämä ei ole aivan tavallista tehdasyhteisötutkimuksissa. Inkeri Ahvenisto kuvailee väitöskirjassaan näkökulmaani seuraavalla tavalla: "Kortelainen kieltäytyy etsimästä yhtä totuutta ja pyrkimästä vanhan historiaperinteen tyyppiseen yhtenäiseen ja ristiriidattomaan tarinaan”. Mielestäni hän on oikeassa.

\section{Muisteltu SAHAYHTEIsö}

Penttilän saha toimi Joensuun kaupungin kupeessa toisella puolella Pielisjokea yli sata vuotta, vuodesta 1871 vuoteen 1988. Sahan ympärille kasvoi tehdasyhdyskunta, jossa asui ja työskenteli suuri joukko ihmisiä: työläisiä, työnjohtajia, tehtaan johtajia, konttoriväkeä, partureita ja kauppiaita, sekä tietenkin heidän perheenjäseniään. Olen rajannut tutkimuksen aineistona olevaa muistitietoa keskittymällä entisten sahatyöläisten ja heidän perheenjäsentensä muistelukerrontaan. Käyttämäni aineisto on suullista, kirjoitettua, valokuvattua ja kartoilla esitettyä muistitietoa. Osa siitä on tuotettu nimenomaan tätä tutkimusta varten, osa on penttiläläisten itse tuottamia aineistoja.

En ole tutkinut varsinaisesti Penttilässä sijainnutta tehdasyhdyskuntaa, vaan kohteena on muisteltu yhteisö, joka lähenee ajatuksena Benedict Andersonin käsitettä kuvitteellisesta yhteisöstä. Tämä yhteisö pitää sisällään monta sukupolvea. Penttilän saha työllisti ihmisiä kolmen tai neljän sukupolven ajan, ja usein sahatyö periytyi perheen sisällä sukupolvelta toiselle. Kaikki muistitietoaineistoissa esiintyvät sahayhteisön ihmiset eivät ole välttämättä kohdanneet toisiaan koskaan. Se pitää sisällään eri aikoina eläneitä ihmisiä ja tapahtumia, jotka nimenomaan muistitieto tunnistaa. Toisaalta tutkimukseni kohteena ovat myös tehdastyöläisyys ja työläisidentiteetti. Työläisyys on monimerkityksellinen käsite: merkitykset riippuvat siitä, missä yhteydessä käsitettä käytetään ja tulkitaan. Koska tämän tutkimuksen aineisto on kerätty 


\section{KaISU KoRTELAINEN}

työläisiltä, on myös näkökulma työläisidentiteettiin heistä itsestään nouseva. Yleiset käsitykset siitä, minkälainen on oikea työläinen tai periaatetyöläinen, tulevat esille myös penttiläläisten muistelukerronnassa. Aineisto kertoo kuitenkin enemmän siitä, mitä työläisyys merkitsi näiden ihmisten ja perheiden jokapäiväisessä elämässä, arjessa ja joskus myös juhlissa. Se kertoo siitä, mitä tehdastyöläisyys merkitsi lasten, naisten tai miesten näkökulmista.

\section{PITKÄAIKAISESTA KENTTÄTYÖSTÄ DISKURSSITUTKIMUKSEEN}

Olen lähestynyt muistelukerrontaa etnografian ja diskurssitutkimuksen lähtökohdista. Nämä valinnat ovat ohjanneet aineistojen tulkintaa ja käyttöä tutkimuksessani. Sekä etnografiaan että diskurssitutkimukseen sisältyy ajatus aineistojen kontekstuaalisesta tulkinnasta. Kun tekstiä tulkitessa otetaan huomioon siihen vaikuttaneita tekijöitä, avautuu tutkijalle tekstistä uusia merkityksiä. Näin kontekstit ovat tulkinnan kanavia. Tällaisina kanavina ovat tutkimuksessani toimineet haastateltavien elämänhistoriat ja -tilanteet, aineistojen tuottamisen tavat ja ympäristön muutokset kenttätyöskentelyn aikana, yleiset teollistumisen kehitysprosessit ja Penttilän sahan historia, ammattiyhdistysliikkeen historia ja yhteiskunnassamme tapahtuneet muutokset. Myös dialogisuus on keskeinen osa tutkimustani. Se liittyy aineiston keruuseen ja tuottamiseen yhdessä haastateltavien kanssa, mutta myös koko tutkimusprosessiin. Tutkijan käsissä eri aikoina tuotetut ja erilaiset tekstit ovat vuorovaikutuksessa keskenään ja tuottavat näin uusia tulkintoja.

Etnografia liittyy ennen kaikkea pitkäaikaiseen kenttätyöhön Penttilässä. Aloitin sen jo vuonna 1989 pian sahan toiminnan lakkauttamisen jälkeen, kun keräsin aineistoa pro gradu -tutkielmaani varten. Kenttätyön eri vaiheita kuvaan väitöskirjani luvussa III. Toisaalta etnografia liittyy myös tutkimuskohteen kuvailemiseen, jota olen tehnyt etenkin väitöskirjani pääluvussa IV "Ajassa kerrostunut paikka". Muistelukerronnassa korostuvat yhteisön paikan rajat, erilaisten paikkojen kuten asuinalueiden, tehdasalueen ja luonnon merkitykset, ympäristön muutokset, liikkuminen paikasta toiseen, arkielämän rytmi, ruumiinmuisti ja aistimuistot sekä naisten ja miesten sekä eri-ikäisten penttiläläisten erilaiset paikkakokemukset.

Olen käsitellyt muistelukerrontaa yhteisön muistina, mutta halunnut kuitenkin korostaa myös yksittäisten henkilöiden erityisyyttä aineistojen tuottamisessa. Esittelen väitöskirjani luvussa V kolme erilaista kertojaa. Väinö Lihavainen oli kirjoittava kertoja, Eino Jokinen on valokuvannut Penttilää 1950-luvun alusta lähtien ja Olavi Karttusen näkemys tehdasyhteisöstä tiivistyy hänen tekemäänsä paikannimityskarttaan. Nämä erilaiset kertojat ja heidän aineistonsa tuovat esille muistitiedon monipuolisuutta, mutta myös yksilön merkitystä yhteisön sisällä.

Olen pohtinut, mistä muistitiedon vahva käsitys "ennen oltiin kuin yhtä perhettä” kumpuaa. Tämä lausahdus esiintyy penttiläläisten muistelupuheessa niin usein, etten voinut ohittaa sitä. Yleinen käsitys siitä, että ihmisillä on tapana kullata menneisyytensä ei riittänyt minulle selitykseksi. Tästä aiheesta oli kuitenkin aika vai- 


\section{MUISTITIETOTUTKIMUS TYÖLÄISYYDESTÄ SAHAYHTEISÖSSÄ}

kea saada kunnollista otetta. Sain selvitettyä, että ainakin osittain siinä on kysymys teollisuuslaitosten sosiaalipolitiikasta, jonka yhtenä tavoitteena oli yhteisöllistäminen. Erityisesti sotien jälkeinen ilmapiiri korosti yleisestikin yhteiskunnassamme yhdessä rakentamista ja kannusti esimerkiksi talkoolaisuuteen.

Diskurssitutkimuksen johdattelemana päädyin analysoimaan muistelukerronnasta teemoja, jotka selittävät yhteisön vuorovaikutusta ja sosiaalista järjestystä. Nämä teemat - valta, vastuu ja yhteishenki - läpäisevät aineistokokonaisuuden ja ovat esillä väitöskirjani pääluvussa VI. Vallan ja vastuun välillä paljastui kamppailu tasapainosta. Vanhoissa tehdasyhdyskunnissa oli selvää, että sillä jolla on valtaa, on myös vastuuta. Se joku oli yleensä tehtaan johtaja, patruuna. Toisaalta työläisten näkökulmasta se, joka kantoi vastuuta ja osasi työnsä, sai myös valtaa. Myös työläiset pystyivät vaikuttamaan eri tavoin työolosuhteisiin, asuinoloihin ja muihin asioihin. Heillä oli omat keinonsa vastustaa herroja tarvittaessa. Päädyin siis eräänlaisen moraaliyhteisön pariin, jossa etsittiin koko ajan vallan, vastuun ja oikeudenmukaisuuden tasapainoa. Tämä on johtanut ajattelemaan, johtuisiko tunne yhteisöllisyyden katoamisesta ainakin osittain näiden kahden asian, vallan ja vastuun, vuorovaikutussuhteen muuttumisesta ja epätasapainosta. Sahan toiminnan lakkauttaminen oli työläisille järkytys ja pettymys: he kokivat, että yhtiö käytti valtaansa väärin eikä enää välittänyt vastuustaan.

\section{MUISTITIEDON KERROSTUVAT TILAT}

Tutkimusta tehdessäni olen työskennellyt kahdessa todellisuudessa. Toisaalta olen elänyt haastateltavieni kanssa yhdessä keskellä Penttilän tilannetta, seuraten keskustelua alueen perinnöstä ja tulevaisuudesta sekä ympäristössä tapahtuneita muutoksia. Toisaalta olen analysoinut haastateltavien tuottamia erilaisia muistitietotekstejä, jotka on tallennettu joko ääninauhoille, kirjoitettuina teksteinä, valokuvina tai karttoina, ja siten ne ovat ikään kuin pysähtyneitä kuvauksia menneestä ja nykyisyydestä. Tähän muistitietotutkijan roolin dilemmaan olen tarttunut työssäni tilan käsitteen avulla. Määrittelen tutkimuksessani toisaalta sen eletyn tilan, jossa itsekin olin ja olen yhäkin mukana. Se on koko ajan kehkeytyvä tila, jossa ihminen, oli hän sitten entinen sahatyöläinen tai yliopistotutkija, saa jatkuvasti uusia virikkeitä ja jossa hänen käsityksensä ovat siten muutoksille alttiita. Sen sijaan tallennetuissa muistitietoaineistoissa esiintyvää maailmaa olen käsitellyt esitetyn tilan käsitteen avulla. Se on tila, jota olen tarkastellut enemmän ulkopuolisena tutkijana ja aineistojen sisäisenä maailmana. Näiden kahden tilan välinen vuorovaikutus on ollut tärkeä osa tutkimusprosessiani ja näkyvillä väitöskirjassani. En ole siis keskittynyt työssäni ainoastaan penttiläläisten kuvaamaan menneisyyteen, vaan mukana on ollut muistitiedolle ominainen ajan kerrostuneisuus: menneisyyden lisäksi nykyisyys ja jossakin määrin myös tieto tai arvelu tulevaisuudesta. Tämä on edesauttanut tavoitteessani käsitellä muistelukerrontaa aineistona, joka on kerrostunutta ja jännitteistä. Näiden kahden erilaisen tilan avoin huomioiminen on myös auttanut minua sijoittamaan itseni ja tutkimukseni Penttilään, jolloin niiden pohtiminen on siis toiminut reflektion välineenä. 


\section{KaISU KoRTELAINEN}

Aikaisemmin jo mainitsin, että aloitin kenttätyöni heti sahan toiminnan lakkauttamisen jälkeen noin 20 vuotta sitten. On kuitenkin mahdotonta sanoa, milloin kenttätyöni on päättynyt tai onko se päättynyt vieläkään. Tuorein väitöskirjassa käsittelemäni varsinainen muistitietoteksti on Olavi Karttusen paikannimityskartta, jonka hän laati vuonna 2005. Olen sen jälkeenkin seurannut Penttilän alueen tapahtumia ja ollut yhteydessä joihinkin haastateltaviini. Minulla on tunne, että prosessi on käynnissä edelleen.

Vaikka kenttätyön aloittamisesta on niin paljon aikaa, on tutkimukseni yhäkin ajankohtainen. Itse asiassa, jos olisin tehnyt työn nopeammin, niin tutkimus olisi aivan erilainen. Minulla ei olisi tietoa ja kokemusta pitkällä aikavälillä tapahtuneista muutoksista Penttilässä, eikä niiden vaikutuksista paikallisten asukkaiden muistitietoon. Minulla ei myöskään olisi käytössäni niitä muistitietotutkimuksen näkökulmia, joita nyt on ollut. Muistitietotutkimus on kehittynyt paljon tänä aikana, ja toivon että tämä väitöskirja tuo siihen vielä jotain uutta. Tehdasyhdyskuntien tutkimuksissa lähestymistapani on uudenlainen ja erilainen, se tuo vahvasti esille tavallisen työläisen näkökulman tehtaalaisuuteen. Paikallistasolla Penttilän alueen tulevaisuus on erittäin ajankohtainen aihe. Tehdasalueelle on suunniteltu rakennettavaksi uusi asuinalue, ja mittava saastuneen maa-aineksen puhdistustyö aloitetaan lähiaikoina. Viimeisetkin näkyvät merkit tehtaan olemassaolosta häviävät. Luulen, että muistitiedon avulla Penttilän sahayhteisön perinnöstä jää kuitenkin jotain jälkiä myös tuleville sukupolville.

\section{KirjallisuUs}

AHVENISTO, INKERI 2008: Tehdas yhdistää ja erottaa Verlassa 1880-luvulta 1960-luvulle. Helsinki: SKS.

ANDERSON, BENEDICT 1983: Imagined Communities. Reflections on the Origin and Spread of Nationalism. London: Verso.

PELTONEN, ULLA-MAIJA 2006: Muistitieto folkloristiikassa. - Fingeroos, Outi, Haanpää, Riina, Heimo, Anne ja Peltonen, Ulla-Maija (toim.), Muistitietotutkimus. Metodologisia kysymyksiä. Helsinki: SKS.

KAISU KORTEL AINEN 2008: Penttilän sahaybteisö ja työlässyys. Muistitietotutkimus. Suomalaisen Kirjallisunden Seuran Toimituksia 1178. Helsinki: Suomalaisen Kirjallisunden Seura.

Filosofian tohtori Kaisu Kortelainen toimii amanuenssina Joensuun yliopiston humanistisessa tiedekunnassa. 